\title{
Understanding the problem of a parent's fear of their child getting cancer from CT scan radiation.
}

Mervyn D. Cohen, MBChB, M.D.

Department of Radiology (Emeritus)

Indiana University

Indianapolis, IN 46202

Corresponding Author

Mervyn D. Cohen, MBChB, M.D.

$317948-6303$

Home 317 873-6586

mecohen@iupui.edu

The author declares that there are no conflicts of interest.

There was no external financial support.

\section{IRB}

No IRB approval was needed for this review

\section{INTRODUCTION}

There is a widespread, exaggerated public perception that one can get cancer from CT scan radiation. This may result in some children being denied clinically indicated CT scans. By understanding how this situation has evolved we can make suggestions for its mitigation. We will review the evolution of the ALARA concept and Image Gently campaigns over the past 15 years. They have generated valuable knowledge that CT scans were being performed using very variable, and in some cases, greater than needed radiation dose. These campaigns have however had some negative outcomes as well. They have helped to create the public's perception that one can get cancer from the radiation used for a CT scan. This perception exists despite the fact

This is the author's manuscript of the article published in final edited form as: 
that $\mathrm{CT}$ radiation induced cancer remains only a hypothesis, without any definite scientific proof. We conclude that parents should not feel anxiety about allowing their children to have medically indicated CT scans.

When parents are made aware of cancer risks of CT scans, they may choose to withdraw their children from those tests $(1,2,3,4)$. The Media (television, radio, magazines) have produced hundreds of headlines in recent years on the topic of CT radiation and cancer (5). Many headlines are constructed to leave the reader with a conclusion that the cancer risk from $\mathrm{CT}$ imaging radiation is much greater than it really is (5).

\section{BACKGROUND.}

The world of CT changed dramatically and the current Media obsession with cancer risk from CT radiation started on the $19^{\text {th }}$ June 2001 with the publication on the front page of the newspaper USA TODAY of an article by Steve Sternberg entitled "CT scans in children linked to cancer" (6). Some readers may have found that the title of this article is alarming. The USA Today article followed three articles in the American Journal of Rontgenology published earlier in $2001(7,8,9)$. The first two articles reported that some CT doses for pediatric CT were higher than they needed to be and could be reduced $(7,8)$. It was the third article by Brenner that got most attention (9). This title of this article was "Estimated Risks of Radiation Induced Fatal Cancer from Pediatric CT". This article caught the media's attention. In the text, Brenner clearly indicated that he was only estimating risk and also indicated uncertainties with his estimates. His report was not based on a scientific study. His results were based on theoretical linear extrapolation of cancer risk from massive radiation exposure that occurred from the Hiroshima atomic bomb. He assumed that there was no threshold for radiation risk and that even the tiniest amount of radiation would result in a very small cancer risk. This is the linear no threshold (LNT) hypothesis. Brenner has been both widely quoted and widely criticized for this assumption. He stated that his predicted, hypothetical risks were very small, representing only a $0.35 \%$ increase in lifetime cancer risk that was not related to radiation exposure. (9). Brenner's cautionary statements were largely ignored by USA Today. The first sentence in Sternberg's USA Today article was "Each year, about 1.6 million children in the USA get CT scans to the head and abdomen — and about 1,500 of these will die later in life of radiationinduced cancer, according to research out today". This was the first of hundreds of similar statements that have 
appeared in the media and in peer reviewed articles that either state or strongly imply that CT radiation induced cancer is a definite fact, and not an unproven hypothesis (Tables 1 and 2).

The USA Today article received incredible attention. Pediatric Radiologists were faced with a terrible dilemma. How should they respond to the USA Today 2001 article? If they rejected the article they would be challenged to provide proof that there was absolutely no risk from medical radiation; a daunting task. They could not endorse the article and start to deny children medically indicated imaging. This also, was not an acceptable solution. They chose the course of adopting the ALARA (As Low as Reasonably Achievable) concept. This aimed to lower unnecessary high radiation doses and also ensure that study indications were valid. Unfortunately the past few years have seen an ever increasing emphasis on the ALARA concept and Image Gently campaigns in the medical community; with an increasing number of scientific peer reviewed publications on the topic. This continues to get the attention of the Media.

\section{ROLE OF THE MEDIA.}

The negative publicity provided by the Media is real. No article title is a lie. However the titles may sometimes be constructed so that the reader is left with an exaggerated conclusion of the risks of getting cancer from a CT scan. The report on Fox News in 2012 titled "Childhood CT scans can triple risk of brain cancer," is frightening (10). What the title does not say is that the risk, if any, is unproven hypothesis and also that it would be triple an existing extremely low incidence of natural occurring brain cancer in children and thus still extremely low.

Consumer Reports, with a readership of over seven million, published 5 frightening articles with titles linking CT to cancer in 2015. One example is "The surprising dangers of CT scan - the cancer risk that lurks in your hospital"' (11).

Since 2001 prestigious newspapers, TV stations and magazines have been frightening the public (our patients) with their overstated articles that CT scans cause cancer. Further examples potentially frightening titles and quotations from Media articles are provided in Table 1. 
The content of all of the media presentations can be discussed under five headings. Subsequent discussion will describe how this media information all originated from peer reviewed scientific articles published in medical journals.

\section{CT scans can cause cancer.}

There are many Media articles making specific statements that CT scans can definitely cause cancer (11-32). Quotation examples are given in Table 1. These may concern parents of our patients.

\section{The dose from CT scans is very high.}

Many Media articles quote scientific publications that refer to the dose from one CT scan being equivalent to between 200 and 500 chest $\mathrm{x}$-rays $(2,11,15,19,20,22-26)$. This may be true, but it does not prove that CT causes cancer.

\section{The use of CT scans has grown very rapidly.}

Since 1980, the number of CT tests done each year has grown from fewer than 3 million to more than 80 million. Many Media reports of rapid increase in CT scans are disturbing to patients who are already scared of getting cancer from a CT scan $(12,13,15-20,24,26,27,31)$.

\section{Children are far more sensitive to radiation-induced carcinogenesis than adults.}

Many Media articles quote scientific publications that claim that children have increased sensitivity to radiation and thus increased risks of cancer from CT scans $(14-18,23)$. These Media articles may distress parents, who are naturally worried about the future health of their children.

\section{Physicians must discuss the risks of CT scans causing cancer with parents and patient's cumulative radiation dose must be recorded.}

Some Media articles, quoting scientific publications, add fear by recommending that patients need to ask the radiologist about the cancer risks of $\mathrm{CT}$, the dose, the technologist's qualification, the facilities accreditation etc? (16-18,21,32 ). Consumer Reports states that "There is no excuse for patients to be uninformed about risks as basic as radiation" (25). 
Adding concern, are media statements that doctors need to do a better job of talking to patients about the risks and benefits of a test that includes radiation exposure (12-14,21,25,31).

\section{MEDICAL PEER REVIEWED JOURNALS AND PROFESSIONAL ORGANIZATIONS.}

We have argued that the Media has some responsibility for spreading fear of CT induced cancer, but this is only partly true. The Medical Profession contributes to the problem. Peer reviewed medical journal articles are creating an environment in which radiation is perceived as 'dangerous' and a cause of cancer. They are the source of material used by the Media for their articles. Examples of potentially frightening quotations from peer reviewed articles are provided in Table 2. We will discuss the content of all of scientific publications under the same five headings that were used above for Media content.

\section{CT scans can cause cancer.}

The relationship between medical imaging radiation and cancer remains uncertain and there is no scientific proof that medical imaging radiation causes cancer.

However, many peer reviewed publications make the claim that even a single CT scan can increase cancer risk (33-47). Some articles clearly state that the risk, if any, is low and based on hypothesis driven by theoretical extrapolation of high dose radiation from the atomic bomb to low doses $(9,35)$. Many articles omit such statements.

Other claims that CT causes cancer are based on dubious epidemiological studies $(5,48$, and 49). With over 800 citations the article by Pearce in Lancet in 2012 is probably the best known. In a 2012 editorial, published in the journal 'Radiology', and titled “Cancer risks from CT Scans: Now We Have Data (proof that CT causes cancer), What Next", Brenner states "Now the first results of the first of several ongoing epidemiologic studies of pediatric CT have recently been published by Pearce et al " $(35,48)$. "The bottom line is that there were significant linear associations between the radiation dose to the brain and the brain tumor risk"(35). The methodology used by Pearce has been severely criticized (5). Pearce studied 178, 000 children in the United 
Kingdom. The methods section states that they "obtained typical machine settings for CT in young people from U.K.-wide surveys undertaken in 1989 and 2003." Review of these surveys reveals that they did not provide this data. The 1989 U.K. survey included no children, only adults. The 2003 survey included only 72 children. Pearce had no control population. He made no allowance for pre-existing conditions that may be linked with cancer. When allowance is made for pre-existing conditions, two large recent epidemiological studies found no relationship between CT scans and cancer $(50$ - 51).

\section{The dose from CT scans is very high.}

Early valid concerns were that pediatric CT scans were being done with excessive radiation; with many institutions not making adjustments on the basis of the examination and using adult exposure settings for children. As a result of national campaigns, this has largely been corrected $(2,7,8,35,4552,53,54)$. While it is intuitively sensible not to use $\mathrm{CT}$ exposure settings greater than needed, this should not be taken as evidence that CT scans cause cancer, as has been done by the Media ( and some scientists).

\section{The use of CT scans has grown very rapidly.}

Many scientific publications refer to a very rapid annual rise in the number of $\mathrm{CT}$ scans being performed $(9,33,37,38,43,45,55)$. The rise in the number of annual CT scans is often viewed as bad, increasing the population radiation exposure and the risk of cancer. No article suggests that this is actually an improvement in health care, making a powerful diagnostic tool, $\mathrm{CT}$, more widely available to our pediatric population.

There are valid arguments that CT is being overused. The arguments against over use of CT should, however, be social and economic and not fear of radiation induced cancer. In reality, most non radiation imaging studies are overused in the USA - this is also probably true for all medical consultations. Why the sole focus on overuse of CT?

\section{Children are far more sensitive to radiation-induced carcinogenesis than adults.}

Claims that children are more sensitive to radiation and are more likely to get cancer from CT scans than adults are found repeatedly in many scientific articles $(9,33,40,45,46,51)$. I do not know if these claims are true or not. What I do know is that this has never been proven. We only have hypotheses, mainly generated by prestigious 
committees, and not by basic scientific research. Authors just quote other authors who have made similar claims without basic scientific studies that prove the hypothesis. An article in 2003 refers to another article and states that this article "superbly demonstrates the increased radio sensitivity of children (10 times that of middle-aged adults)" (42). Unfortunately this referenced article does no original experimental work but just quotes other authors and states "Considerations unique to the pediatric population include increased radio sensitivity of certain tissues, particularly in infancy, a longer lifetime for radiation-related cancer to occur." (41). Thus is the story that children are more sensitive to radiation than adults perpetuated, without any scientific proof.

\section{Physicians must discuss the risks of $\mathrm{CT}$ scans causing cancer with parents and patients.}

There are advocates that risks of CT radiation should always be discussed with the patient and that informed consent should be required for imaging with ionizing radiation (56). One may question the value of these discussions with the patient. The risk, if any, of cancer from CT scans is tiny; the topic is extremely complex and the discussion can only frighten the patient. It does not add value to patient care and is expensive in terms of time resources.

\section{ROLE OF ALARA, IMAGE GENTLY and NATIONAL SOCIETIES.}

The Alliance for Radiation Safety in Pediatric Imaging is known as Image Gently (57). It is currently affiliated with more than 86 national and international organizations $(57,58)$. Frush, a co-chair of the Alliance says "at the heart of the matter is the potential risk of medical imaging radiation-induced cancer in children resulting from a CT scan" (57). Without the impetus of ALARA and the Image Gently Alliance, it is highly probable that we would not have seen the hundreds of peer reviewed scientific articles on CT dose and cancer published over the past 15 years.

\section{CONCLUSION.}

We are not saying that imaging radiation cannot cause cancer. This is not known. One can, however, make a powerful case that the risk of CT causing cancer is based purely on hypotheses that remain unproven by rigid 
scientific studies. We have evolved from hypothesis to accepted fact, without the customary scientific experiment and proof. The risk of CT radiation, if any, is tiny and well below the risks of many other imaging and medical patient interactions, and less than well accepted risks of normal daily living.

We have argued that the ongoing publication of peer reviewed scientific articles dealing with CT radiation is partly responsible for the ongoing Media publication of articles that are causing widespread public fear of CT scans. The general public's perception of the risks from imaging radiation exceeds reality. Our parents may become scared of letting their children have needed CT investigations, because they fear cancer from the CT radiation. Parents need to be advised that if their child is prescribed a medically indicated CT scan, they should agree to the scan with absolutely no worry or concern about cancer risks from the CT study.

Table1: Titles and Quotations from recent Media articles on the subject on CT and Cancer.

\begin{tabular}{|c|c|c|}
\hline REFERENCE & TITLE & QUOTE from the article \\
\hline $\begin{array}{l}\text { ABC KVUE Austin } \\
2015\end{array}$ & $\begin{array}{l}\text { Risks of CT scans for kids' } \\
\text { concussions }\end{array}$ & $\begin{array}{l}\text { Radiation from CT scans increases the risk of } \\
\text { cancer }\end{array}$ \\
\hline $\begin{array}{l}\text { ABC eyewitness news } \\
2015\end{array}$ & $\begin{array}{l}\text { Head CAT scans for kids could be } \\
\text { unnecessary, risk }\end{array}$ & $\begin{array}{l}\text { Radiation from C-T scans increases the risk of } \\
\text { cancer. }\end{array}$ \\
\hline $\begin{array}{l}\text { ABC news } \\
2015\end{array}$ & CAT scan alert & CAT scans can lead to serious consequences. \\
\hline $\begin{array}{l}\text { ABC News } \\
2013\end{array}$ & $\begin{array}{l}\text { Cancer patient concerned about } \\
\text { multiple CT scans }\end{array}$ & $\begin{array}{l}\text { CT scan, the radiation dose can be } 100-500 \text { times } \\
\text { more than an X-ray. }\end{array}$ \\
\hline $\begin{array}{l}\text { ABC TV } \\
2015\end{array}$ & Overuse of CT scans & $\begin{array}{l}\text { CT scans may be responsible for at least } 2 \\
\text { percent of future cancers in the U.S }\end{array}$ \\
\hline $\begin{array}{l}\text { CBS News } \\
2014\end{array}$ & CT Scan Radiation Risks & $\begin{array}{l}\text { Full-body CT scans themselves pose a real } \\
\text { cancer risk }\end{array}$ \\
\hline $\begin{array}{l}\text { CBS news } \\
2015\end{array}$ & $\begin{array}{l}\text { Risks of cancer-causing radiation from X- } \\
\text { rays, CT scans }\end{array}$ & CT scans can lead to cancer \\
\hline $\begin{array}{l}\text { CBS this morning } \\
\text { Jan } 2015\end{array}$ & $\begin{array}{l}\text { Risks of cancer-causing radiation } \\
\text { from X-rays, CT scans }\end{array}$ & $\begin{array}{l}\text { CT scans can lead to cancer } 2 \% \text { of all future } \\
\text { cancers }\end{array}$ \\
\hline $\begin{array}{l}\text { Center for advancement } \\
\text { in Cancer } \\
\text { Education } 2015\end{array}$ & $\begin{array}{l}15 \text { Disturbing Facts About CT } \\
\text { Scan Safety }\end{array}$ & CT scanning definitely increases cancer risk \\
\hline $\begin{array}{l}\text { Columbus dispatch } \\
2012\end{array}$ & $\begin{array}{l}\text { How many imaging scans are too } \\
\text { many? }\end{array}$ & $\begin{array}{l}\text { Dental patients should not be subjected to regular } \\
\text { or even annual X-rays. Cumulative radiation } \\
\text { exposure has been shown to cause cancer }\end{array}$ \\
\hline $\begin{array}{l}\text { Consumer Reports } \\
\text { January } 2015\end{array}$ & $\begin{array}{l}\text { When to question CT scans and X- } \\
\text { rays? Radiation from these tests } \\
\text { can increase your cancer risk }\end{array}$ & $\begin{array}{l}\text { Roughly a third of them (CT scans) serve little if } \\
\text { any medical purpose }\end{array}$ \\
\hline
\end{tabular}




\begin{tabular}{|c|c|c|}
\hline $\begin{array}{l}\text { Consumer reports } \\
\text { Jan } 272015\end{array}$ & $\begin{array}{l}\text { The surprising dangers of CT scans } \\
\text { and X-rays. Patients are often } \\
\text { exposed to cancer-causing } \\
\text { radiation for little medical reason, } \\
\text { a Consumer Reports investigation } \\
\text { finds }\end{array}$ & $\begin{array}{l}\text { Research shows that today's medical patients are } \\
\text { being harmed (from CT radiation) }\end{array}$ \\
\hline $\begin{array}{l}\text { Consumer Reports } \\
\text { Feb } 6^{\text {th }} 2015\end{array}$ & Can mammograms cause cancer? & $\begin{array}{l}\text { What do you think is more likely to cause breast } \\
\text { cancer: chemicals such as BPA, phthalates, and } \\
\text { pesticides or imaging tests such as X-rays and } \\
\text { CT scans? The surprising answer: the imaging } \\
\text { tests, particularly CT scans }\end{array}$ \\
\hline $\begin{array}{l}\text { Consumer Reports } \\
\text { Jan 28th, } 2015\end{array}$ & $\begin{array}{l}\text { What to do if you think your child } \\
\text { has a concussion. Getting a CT } \\
\text { scan when it's not needed poses } \\
\text { risks }\end{array}$ & $\begin{array}{l}\text { More and more parents arrive in the ER with the } \\
\text { idea that their visit won't be complete without a } \\
\text { head CT }\end{array}$ \\
\hline $\begin{array}{l}\text { Consumer reports } \\
\text { April } 2014\end{array}$ & Dangers of too many CT scans & $\begin{array}{l}\text { But the tests }(\mathrm{CT}) \text { pose risks, too, by exposing } \\
\text { you to cancer-causing radiation }\end{array}$ \\
\hline $\begin{array}{l}\text { Consumer Reports } \\
\text { December 22, } 2009\end{array}$ & Is that CT scan worth the risk? & A CT scan is the equivalent of 442 chest $\mathrm{x}$-rays \\
\hline $\begin{array}{l}\text { Consumer Reports } \\
\text { January } 03,2013\end{array}$ & $\begin{array}{l}\text { Many patients unaware of } \\
\text { radiation risks from CT scans }\end{array}$ & $\begin{array}{l}\text { Only } 5 \text { percent (of patients) understood that scan } \\
\text { radiation might increase their lifetime risk of } \\
\text { cancer }\end{array}$ \\
\hline $\begin{array}{l}\text { Consumer Reports } \\
\text { March 05, } 2015\end{array}$ & $\begin{array}{l}\text { The cancer risk that lurks in your } \\
\text { hospital }\end{array}$ & $\begin{array}{l}\text { Radiation from the scans contribute to an } \\
\text { estimated } 15,000 \text { cancer deaths a year }\end{array}$ \\
\hline $\begin{array}{l}\text { ConsumerReports: } \\
\text { February } 24,2010\end{array}$ & $\begin{array}{l}\text { Do multiple X-rays increase my } \\
\text { risk of developing cancer? }\end{array}$ & $\begin{array}{l}\text { Nearly all X-rays expose you to radiation that } \\
\text { increases your cancer risk }\end{array}$ \\
\hline $\begin{array}{l}\text { Daily Mail UK } \\
2014\end{array}$ & $\begin{array}{l}\text { Do regular mammograms raise the } \\
\text { risk of cancer? }\end{array}$ & $\begin{array}{l}\text { The process is not without risks ... the damage } \\
\text { from radiation (from the mammograms) }\end{array}$ \\
\hline $\begin{array}{l}\text { Dallas Morning News } \\
2014\end{array}$ & We are giving ourselves cancer & $\begin{array}{l}\text { The relationship between radiation and the } \\
\text { development of cancer is well understood }\end{array}$ \\
\hline $\begin{array}{l}\text { Dallas Morning News } \\
2014\end{array}$ & We are giving ourselves cancer. & $\begin{array}{l}\text { There is distressingly little evidence of better } \\
\text { health outcomes associated with the current high } \\
\text { rate of (CT) scans. We are silently irradiating } \\
\text { ourselves to death }\end{array}$ \\
\hline $\begin{array}{l}\text { Examiner.com } \\
2013\end{array}$ & $\begin{array}{l}\text { Too much radiation from } \mathrm{CT} \\
\text { scans can cause cancer }\end{array}$ & $\begin{array}{l}\text { Potential significant risk of developing cancer } \\
\text { as a result of the test itself }\end{array}$ \\
\hline Express-times 2014 & $\begin{array}{l}\text { Be aware of radiation exposure to } \\
\text { pre-schoolers }\end{array}$ & $\begin{array}{l}\text { Children's bodies are particularly susceptible to } \\
\text { harmful changes in their brains and blood after } \\
\text { exposure (to radiation) }\end{array}$ \\
\hline $\begin{array}{l}\text { Fox news } \\
\text { June } 2012\end{array}$ & $\begin{array}{l}\text { Childhood CT scans can triple risk } \\
\text { of brain cancer }\end{array}$ & $\begin{array}{l}\text { Exposing a child to the radiation from two or } \\
\text { three computed tomography (CT) head scans can } \\
\text { triple its risk of developing brain cancer later in } \\
\text { life }\end{array}$ \\
\hline $\begin{array}{l}\text { Fox news } \\
2013\end{array}$ & $\begin{array}{l}\text { Many people unaware of radiation } \\
\text { risk from CT scans }\end{array}$ & $\begin{array}{l}\text { National Cancer Institute estimated there would } \\
\text { be about } 29,000 \text { future cancers related to scans } \\
\text { done in } 2007 \text { alone }\end{array}$ \\
\hline $\begin{array}{l}\text { Good Housekeeping } \\
2015\end{array}$ & $\begin{array}{l}\text { Overexposed: The Startling Truth } \\
\text { about CT Scans }\end{array}$ & $\begin{array}{l}\text { OK Today, Cancer Tomorrow. CT scans deliver } \\
\text { radiation - a whopping dose compared with } \\
\text { regular X-rays }\end{array}$ \\
\hline
\end{tabular}




\begin{tabular}{|c|c|c|}
\hline $\begin{array}{l}\text { Health Magazine } \\
\text { Graves } 2014\end{array}$ & $\begin{array}{l}\text { The Hidden Dangers of Medical } \\
\text { Scans }\end{array}$ & $\begin{array}{l}\text { One factor that's strongly associated with risk of } \\
\text { developing the disease (breast cancer)is ionizing } \\
\text { radiation. }\end{array}$ \\
\hline $\begin{array}{l}\text { Healthline News } \\
2013\end{array}$ & $\begin{array}{l}\text { Children's Cancer Risks Increase } \\
\text { With Use of CT Scans }\end{array}$ & $\begin{array}{l}\text { The risk of cancer from radiation exposure is too } \\
\text { high a price to pay for diagnostic certainty. the } \\
\text { benefits of CT scans in children do not outweigh } \\
\text { the risks }\end{array}$ \\
\hline $\begin{array}{l}\text { Huffington post } \\
2011\end{array}$ & $\begin{array}{l}\text { Why We Should Think Twice } \\
\text { About Getting A CT Scan }\end{array}$ & $\begin{array}{l}\text { They (CT SCANS) expose patients to radiation } \\
\text { thatcan hurt and even kill them. }\end{array}$ \\
\hline $\begin{array}{l}\text { Huffington Post } \\
2012\end{array}$ & $\begin{array}{l}\text { CT Scans in Children: Benefit and } \\
\text { Risks }\end{array}$ & Are CT scans dangerous? Yes! \\
\hline $\begin{array}{l}\text { Huffington post } \\
2014\end{array}$ & $\begin{array}{l}5 \text { Frightening, Lifesaving Things } \\
\text { to Know About CT Scans, Side } \\
\text { Effects, and Cancer }\end{array}$ & $\begin{array}{l}\text { Abdominal CT equaling approximately } 300 \text { chest } \\
\text { X-rays }\end{array}$ \\
\hline $\begin{array}{l}\text { Medical News Today } \\
2014\end{array}$ & $\begin{array}{l}\text { Exposure to radiation in childhood } \\
\text { increases risk for brain tumors }\end{array}$ & $\begin{array}{l}\text { We have become more aware of the tumor- } \\
\text { inducing properties of radiation. }\end{array}$ \\
\hline $\begin{array}{l}\text { Medical News Today } \\
2013\end{array}$ & $\begin{array}{l}\text { CT Scans Associated With } \\
\text { Increased Cancer Risk }\end{array}$ & $\begin{array}{l}\text { Pediatric CT scans could be responsible for an } \\
\text { estimated } 4,870 \text { future cancers every year }\end{array}$ \\
\hline $\begin{array}{l}\text { Memorial Sloan Kettering } \\
2015\end{array}$ & $\begin{array}{l}\text { On Cancer: Scan Safety: A } \\
\text { Radiation Reality Check }\end{array}$ & $\begin{array}{l}\text { A number of patients refuse imaging exams } \\
\text { because they are afraid of the risks associated } \\
\text { with them }\end{array}$ \\
\hline $\begin{array}{l}\text { NBC News 9Denver } \\
2015\end{array}$ & $\begin{array}{l}\text { Risks of CT scans for kids' } \\
\text { concussions }\end{array}$ & $\begin{array}{l}\text { Radiation from CT scans increases the risk of } \\
\text { cancer }\end{array}$ \\
\hline $\begin{array}{l}\text { NBC } 5 \text { Dallas } \\
2015\end{array}$ & $\begin{array}{l}\text { Risks of CT scans for kids' } \\
\text { concussions }\end{array}$ & $\begin{array}{l}\text { Radiation from CT scans increases the risk of } \\
\text { cancer }\end{array}$ \\
\hline $\begin{array}{l}\text { NBC news } \\
2015\end{array}$ & A warning about CT scans & $\begin{array}{l}\text { CT scans may be responsible for at least two } \\
\text { percent of future cancers in the United States }\end{array}$ \\
\hline $\begin{array}{l}\text { NBC News } \\
2010\end{array}$ & $\begin{array}{l}\text { Biggest radiation threat is due to } \\
\text { medical scans }\end{array}$ & $\begin{array}{l}\text { Too much radiation raises the risk of cancer. "I } \\
\text { was horrified" at the cancer risk it posed. } \\
\text { Patients under } 40 \text { who had had five (CT scans); } \\
\text { clearly dangerous amounts. }\end{array}$ \\
\hline $\begin{array}{l}\text { New York times } \\
2010\end{array}$ & $\begin{array}{l}\text { Radiation Worries for Children in } \\
\text { Dentists' Chairs }\end{array}$ & $\begin{array}{l}\text { The dental profession had problems keeping } \\
\text { radiation levels low }\end{array}$ \\
\hline $\begin{array}{l}\text { New York Times } \\
2014\end{array}$ & We Are Giving Ourselves Cancer & We are silently irradiating ourselves to death \\
\hline $\begin{array}{l}\text { New York Times } \\
2014\end{array}$ & We are giving ourselves cancer. & $\begin{array}{l}\text { A single CT scan exposes a patient to the amount } \\
\text { of radiation that epidemiologic evidence shows } \\
\text { can be cancer-causing }\end{array}$ \\
\hline $\begin{array}{l}\text { Newsmax } \\
2013\end{array}$ & $\begin{array}{l}\text { Doctors Often Dont Reveal CT } \\
\text { Scan Dangers }\end{array}$ & $\begin{array}{l}\text { Found people are unaware of the radiation risks } \\
\text { posed by CT scans }\end{array}$ \\
\hline $\begin{array}{l}\text { NPR } \\
2009\end{array}$ & $\begin{array}{l}\text { Radiation From CT Scans May } \\
\text { Raise Cancer Risk }\end{array}$ & $\begin{array}{l}\text { Physicians [and their patients] cannot be } \\
\text { complacent about the hazards of radiation or we } \\
\text { risk creating a public health time bomb }\end{array}$ \\
\hline $\begin{array}{l}\text { NPR } \\
2013\end{array}$ & $\begin{array}{l}\text { How CT Scans Have Raised } \\
\text { Kids' Risk For Future Cancer }\end{array}$ & $\begin{array}{l}\text { The radiation used in the tests }(\mathrm{CT}) \text { increases } \\
\text { children's lifelong risk of cancer. }\end{array}$ \\
\hline $\begin{array}{l}\text { Nursing times } \\
2014\end{array}$ & $\begin{array}{l}\text { Caution urged over CT scan } \\
\text { radiation doses }\end{array}$ & Radiation is also recognised as a carcinogen \\
\hline $\begin{array}{l}\text { Nutrition Facts } \\
2014\end{array}$ & How Risky are CT Scans? & $\begin{array}{l}\text { Radiologists have not been watching out for } \\
\text { children. A few CT scans may triple the risk of }\end{array}$ \\
\hline
\end{tabular}




\begin{tabular}{|c|c|c|}
\hline & & brain tumors and leukemia in children. \\
\hline $\begin{array}{l}\text { Roseville Newspaper } \\
2014\end{array}$ & $\begin{array}{l}\text { CT Scans Carry Cancer Risk for } \\
\text { Young Patients }\end{array}$ & $\begin{array}{l}\text { Radiation exposure in the brains of developing } \\
\text { children is of particular concern }\end{array}$ \\
\hline $\begin{array}{l}\text { Scientific American } \\
2013\end{array}$ & $\begin{array}{l}\text { How Much Do CT Scans Increase } \\
\text { the Risk of Cancer }\end{array}$ & $\begin{array}{l}\text { CT scanners bombard the human body with x-ray } \\
\text { beams, which can damage DNA and create } \\
\text { mutations that spur cells to grow into tumors }\end{array}$ \\
\hline $\begin{array}{l}\text { Slate.com } \\
2012\end{array}$ & $\begin{array}{l}\text { What Your Doctors Dont Know } \\
\text { Can Hurt You. Is your physician } \\
\text { increasing your risk for cancer? }\end{array}$ & $\begin{array}{l}\text { That medical imaging, particularly CT scanning, } \\
\text { remains a major and often overlooked risk factor } \\
\text { for breast cancer. }\end{array}$ \\
\hline $\begin{array}{l}\text { The Independent } \\
2015\end{array}$ & $\begin{array}{l}\text { Radiation risks from CT Scans and } \\
\text { MRI }\end{array}$ & $\begin{array}{l}\text { radiation from X-rays damages the DNA which } \\
\text { can cause cancer }\end{array}$ \\
\hline New American 2014 & $\begin{array}{l}\text { U.S. Navy Sailors Sue Over Low- } \\
\text { dose Radiation }\end{array}$ & $\begin{array}{l}\text { U.S. sailors are suing a Japanese utility for } \\
\text { exposing them to nuclear radiation during a } 2011 \\
\text { humanitarian mission to aid tsunami victims }\end{array}$ \\
\hline $\begin{array}{l}\text { Time magazine } \\
2008\end{array}$ & How Dangerous Are CT Scans? & $\begin{array}{l}\text { One-third of all CT scans performed in the } \\
\text { United States are unnecessary. A child's risk of } \\
\text { developing a fatal cancer from one CT scan is as } \\
\text { high as } 1 \text { in } 500\end{array}$ \\
\hline $\begin{array}{l}\text { Time magazine } \\
2013\end{array}$ & $\begin{array}{l}\text { To Scan or Not to Scan: Largest } \\
\text { Study to Date Links Childhood } \\
\text { CTs to Increased Cancer Risk }\end{array}$ & $\begin{array}{l}\text { Those who had two to three (CT) scans in } \\
\text { childhood tripled their risk of later developing } \\
\text { brain tumors. }\end{array}$ \\
\hline $\begin{array}{l}\text { UK Healthcare } \\
2015\end{array}$ & $\begin{array}{l}\text { Studies examine radiation } \\
\text { exposure, long-term cancer risks of } \\
\text { CT scans }\end{array}$ & $\begin{array}{l}\text { Radiation exposure associated with computed } \\
\text { tomography (CT) scans have raised concerns } \\
\text { about long-term cancer risks }\end{array}$ \\
\hline $\begin{array}{l}\text { USA Today } \\
2013\end{array}$ & Experts weigh risks of CT scans & $\begin{array}{l}\text { A quarter to a third of all CT scans are } \\
\text { unnecessary }\end{array}$ \\
\hline $\begin{array}{l}\text { Webmd } \\
2009\end{array}$ & $\begin{array}{l}\text { Are CT Scans Sometimes Too } \\
\text { Risky? }\end{array}$ & $\begin{array}{l}\text { Radiation doses from CT scans are often high } \\
\text { and vary widely, and excessively high doses may } \\
\text { contribute substantially to future cancers }\end{array}$ \\
\hline $\begin{array}{l}\text { Whitaker Wellness } \\
\text { Institute } \\
2014 \\
\end{array}$ & $\begin{array}{l}\text { Medical Radiation Increases } \\
\text { Cancer Risk Factors }\end{array}$ & $\begin{array}{l}\text { It }(\mathrm{CT}) \text { also has a potentially deadly side effect, } \\
\text { increasing your cancer risk factors. }\end{array}$ \\
\hline $\begin{array}{l}\text { Wisconsin TV news } \\
\text { channel } 3000 \\
2015\end{array}$ & $\begin{array}{l}\text { Risks of CT scans for kids' } \\
\text { concussions }\end{array}$ & $\begin{array}{l}\text { Radiation from CT scans increases the risk of } \\
\text { cancer }\end{array}$ \\
\hline $\begin{array}{l}\text { Women's Health } \\
\text { Activist } \\
2012 \\
\end{array}$ & CT Scan Safety & Radiation exposure causes cancer \\
\hline $\begin{array}{l}\text { World Net Daily } \\
2013\end{array}$ & $\begin{array}{l}\text { Parents alarmed over routine ct- } \\
\text { scan dangers }\end{array}$ & $\begin{array}{l}\text { Parents may not be aware of the associated risks } \\
\text { (of CT), including a lifetime increased risk of } \\
\text { cancer. }\end{array}$ \\
\hline
\end{tabular}

Table 2: Quotations from peer reviewed, scientific publications on the subject on CT and Cancer.

\begin{tabular}{|l|l|}
\hline REFERENCE & QUOTE from the article. \\
\hline Bogdanich & Many experts in dental radiation have raised alarms about what they see as their \\
\hline
\end{tabular}




\begin{tabular}{|c|c|}
\hline 2010 & (dental CT scans) indiscriminate use \\
\hline Brenner 2001 & $\begin{array}{l}\text { Assess the lifetime cancer mortality risks attributable to radiation from pediatric } \\
\text { CT. The best available risk estimates suggest that pediatric CT will result in } \\
\text { significantly increased lifetime radiation risk over adult CT }\end{array}$ \\
\hline Brenner 2010 & $\begin{array}{l}\text {.but there is persuasive evidence, at the doses relevant to } \mathrm{CT} \text {, that the risks of } \\
\text { radiation carcinogenesis are real }\end{array}$ \\
\hline Brenner 2012 & $\begin{array}{l}\text { The bottom line is that there were significant linear associations between the } \\
\text { radiation dose to the brain and the brain tumor risk }\end{array}$ \\
\hline Donnelly 2001 & $\begin{array}{l}\text { A major disadvantage with this increased use of helical CT is the associated } \\
\text { radiation exposure. }\end{array}$ \\
\hline Donnelly 2003 & Low-dose radiation (such as that in $\mathrm{CT}$ ) may have a significant risk of cancer \\
\hline Fazel 2014 & $\begin{array}{l}\text { the ordering physician ensure that the patient is aware of and understands the } \\
\text { potential risks related to the radiation exposure }\end{array}$ \\
\hline Goske 2008 & $\begin{array}{l}\text { The message of the Image Gently campaign is simple: Reduce or "child-size" } \\
\text { the amount of radiation used when obtaining a CT scan in children }\end{array}$ \\
\hline Graves 2014 & $\begin{array}{l}\text { Limiting exposure to medical radiation should be on every woman's cancer- } \\
\text { prevention list }\end{array}$ \\
\hline Lange 2014 & $\begin{array}{l}\text { Females who were treated with chest radiation for Wilms tumor had a high risk } \\
\text { of developing early breast cancer }\end{array}$ \\
\hline Lauer 2009 & $\begin{array}{l}\text { Irradiation represents a direct danger imposed by a physicians decision to refer a } \\
\text { patient for CT imaging }\end{array}$ \\
\hline $\begin{array}{l}\text { Miglioretti } \\
2013\end{array}$ & $\begin{array}{l}\text { Among girls, depending on the age, a solid cancer induced by radiation is } \\
\text { projected to result from } 300 \text { to } 390 \text { scans in the abdomen/pelvis }\end{array}$ \\
\hline $\begin{array}{l}\text { Miglioretti } \\
2013\end{array}$ & $\begin{array}{l}\text { Nationally, } 4 \text { million pediatric CT scans of the head, abdomen/pelvis, chest, or } \\
\text { spine performed each year are projected to cause } 4870 \text { future cancers }\end{array}$ \\
\hline Muratore 2013 & Pediatric abdominal CT scans: do it correctly. Better yet, don't do it at all \\
\hline Paterson 2001 & $\begin{array}{l}\text { The principal long-term disadvantage of CT is radiation exposure. This is } \\
\text { especially important in children because the younger the patient is at the time of } \\
\text { exposure to radiation the greater is this risk }\end{array}$ \\
\hline Redberg 2009 & $\begin{array}{l}\text { Whether these scans (CT) will lead to demonstrable benefits through } \\
\text { improvements in longevity or quality of life is hotly debated }\end{array}$ \\
\hline Redberg 2009 & $\begin{array}{l}\text { The explosion of CT scans in the past decade has outpaced evidence of their } \\
\text { benefit. One in every } 270 \text { forty-year-old women undergoing a CT coronary } \\
\text { angiogram will develop cancer from the procedure. }\end{array}$ \\
\hline $\begin{array}{l}\text { Schroeder } \\
2013\end{array}$ & $\begin{array}{l}\text { Concerns over radiation-induced malignancy (from CT) continue to mount in } \\
\text { the popular and scientific press. Iit is well accepted that the malignancy risks } \\
\text { from CT induced radiation are real and that children are particularly vulnerable }\end{array}$ \\
\hline Slovis 2003 & They superbly demonstrate the increased radio sensitivity of children \\
\hline $\begin{array}{l}\text { Smith- } \\
\text { Bindman } 2010\end{array}$ & $\begin{array}{l}\text { We found that the risk of cancer from a single } \mathrm{CT} \text { scan could be as high as } 1 \text { in } \\
80\end{array}$ \\
\hline Sternberg 2001 & $\begin{array}{l}\text { These doses (CT) are "way bigger than the sorts of doses that people at Three } \\
\text { Mile Island were getting," }\end{array}$ \\
\hline Stratton 2010 & $\begin{array}{l}\text { As a liaison between radiologist and parents, the urologist should also be able to } \\
\text { explain the possible risks and alternatives to the patient family }\end{array}$ \\
\hline Voss 2009 & $\begin{array}{l}\text { Numerous reports have emphasized that even low doses of radiation exposure, } \\
\text { such as those occurring during radiological examinations, can lead to long-term } \\
\text { adverse health outcomes, most notably increases in risk of malignancy }\end{array}$ \\
\hline Willis 2004 & Research indicates an increased risk of childhood acute lymphocytic leukemia \\
\hline
\end{tabular}




\begin{tabular}{|l|l|}
\hline & $\begin{array}{l}\text { from plain film studies and an increased risk of fatal breast cancer from scoliosis } \\
\text { series }\end{array}$ \\
\hline Willis 2004 & No level of radiation exposure is without consequence, \\
\hline
\end{tabular}

\section{REFERENCES.}

1. World Net Daily. Parents Alarmed Over Routine Ct-Scan Dangers. Support for testing plunges when radiation risk revealed. Gina Loudon. 07/08/2013. http://www.wnd.com/2013/07/parents-alarmed-over-routinect-scan-dangers/\#sWfRP0E09gBitUEG.99 Accessed February/March 2015.

2. Memorial Sloan Kettering Cancer News and Insights. Scan Safety: A Radiation Reality Check. Napolitano BS. February 4, 2015 http://www.mskcc.org/blog/scan-safety-radiation-reality-check Accessed February/March 2015.

3. Scudder L, Brody A. CT Radiation in Kids: How Much of a Risk, Really?Medscape June 05, 2014. http://www.medscape.com/viewarticle/826119 2 Accessed February/March 2015.

4.BoutisK, Cogollo W, Fischer J, Freedman SB, et al. Parental Knowledge of Potential Cancer Risks From Exposure to Computed Tomography. Pediatrics 2013;132, doi: 10.1542/peds.2013-0378)

5. Cohen MD, ALARA, Image Gently and CT-induced cancer. Pediatric Radiology 2015; 45:465-470

6. USA Today. CT scans in children linked to cancer. Steve Sternberg.

1.22.2001http://usatoday30.usatoday.com/news/nation/2001-01-22-scans.htm Accessed February/March 2015.

7. Donnelly L, Emery KH, Brody AS.et al. Minimizing Radiation Dose for Pediatric Body. Applications of Single-Detector Helical CT: Strategies at a Large Children's Hospital AJR 2001;176: 303-306

8. Paterson A, Frush DP, Donnelly L. Helical CT of the Body: Are SettingsAdjusted for Pediatric Patients? AJR 2001;176:297-301 
9. Brenner DJ, Elliston CD, Hall EJ, Berdon WE. Estimated Risks of Radiation Induced Fatal Cancer from Pediatric CT AJR. 2001; 176: 289-296

10. Fox TV News. Childhood CT scans can triple risk of brain cancer. June 7, 2012http:/www.foxnews.com/health/2012/06/07/childhood-ct-scans-can-triple-risk-brain-cancer/ Accessed February/March 2015.

11. Consumer Reports: March 05, 2015. The cancer risk that lurks in your hospital. Unnecessary CT scans are far too common in U.S. http://www.consumerreports.org/cro/news/2015/03/the-cancer-risk-that-lurks-in-yourhospital/index.htm Accessed February/March 2015.

12. NBC news Americans get most medical radiation in world; dose has grown six fold. Marilynn Marchione. 6/14/2010 http://www.nbcnews.com/id/37623994/ns/health-health care/t/biggest-radiation-threat-due-medicalscans/\#.VQhESmt0x9A Accessed February/March 2015.

13. NBC 9 news Denver Colorado, CAT Scan Dangers. Mark Koebrich. January 28, 2015 http://www.9news.com/story/money/personal-finance/consumer/2015/01/28/cat-scan-dangers/22478593 Accessed February/March 2015.

14. ABC eyewitness news - WABC TV New York. Head CAT scans for kids could be unnecessary, risky. March 05, 2015 http://7online.com/health/consumer-reports-head-cat-scans-for-kids-could-be-unnecessaryrisky/546008/ Accessed February/March 2015.

15. USA today. Experts weigh risks of CT scans. Liv Osby, March 21, $2013 \mathrm{http}: / / \mathrm{www}$ .usatoday.com/story/news/nation/2013/03/21/ct-scan-concerns/2005729/ Accessed February/March 2015. 16. NPR How CT Scans Have Raised Kids' Risk For Future Cancer. Nancy Shute. June 11, 2013. Http://www.npr.org/blogs/health/2013/06/10/190449001/how-ct-scans-have-raised-kids-risk-for-future-cancer Accessed February/March 2015.

17. Time. How Dangerous Are CT Scans? Catherine Guthrie. June 27, 2008.

http://content.time.com/time/health/article/0,8599,1818520,00.html Accessed February/March 2015. 
18. Nutrition Facts. How Risky are CT Scans? Michael Greger February 13th, 2014

http://nutritionfacts.org/2014/02/13/how-risky-are-ct-scans/ Accessed February/March 2015.

19. Time inc. Health magazine. The Hidden Dangers of Medical Scans. Medical imaging tests are exposing more of us to potentially cancer-causing radiation. Ginny Graves. November 11, 2014

http://www.health.com/health/article/0,20871394 last,00.html Accessed February/March 2015.

20. The Examiner. Too much radiation from CT scans can cause cancer. Deborah Shlian. July 30, 2013

http://www.examiner.com/article/too-much-radiation-from-ct-scans-can-cause-cancer. Accessed

February/March 2015.

21. Slate.com What Your Doctors Dont Know Can Hurt You. Is your physician increasing your risk for cancer? Anna Reisman. Aug 12012

http://www.slate.com/articles/double_x/doublex/2012/08/ct scans and cancer is your_doctor increasing you r_risk_with_all that medical_imaging_html Accessed February/March 2015.

22. Huffington Post. 5 Frightening, Lifesaving Things to Know About CT Scans, Side Effects, and Cancer.

Paul Sanderson. 12/14/2014. http://www.huffingtonpost.com/paul-sanderson/5-frightening-things-to-

k b 5918652.html Accessed February/March 2015.

23. Scientific American. How Much Do CT Scans Increase the Risk of Cancer? Carina Storrs. Jun 18, 2013

http://www.scientificamerican.com/article/how-much-ct-scans-increase-risk-cancer/ Accessed February/March 2015.

24. Consumer Reports: December 22, 2009 Is that CT scan worth the risk?

http://www.consumerreports.org/cro/news/2009/12/is-that-ct-scan-worth-the-risk/index.htm Accessed February/March 2015.

25. Consumer Reports: January 03, 2013. Many patients unaware of radiation risks from CT scans. http://www.consumerreports.org/cro/news/2013/01/many-patients-unaware-of-radiation-risks-from-ctscans/index.htm Accessed February/March 2015. 
26. Dallas morning news. We are giving ourselves cancer. Rita F. Redberg and Rebecca Smith-Bindman

\subsubsection{4 http://www.dallasnews.com/opinion/sunday-commentary/20140207-we-are-giving-ourselves-}

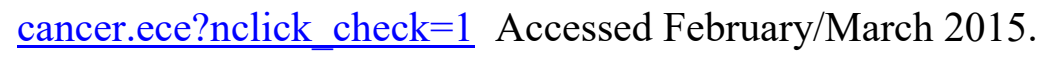

27. New York Times. Op-Ed . We Are Giving Ourselves Cancer. Redberg RF, Smith-bindman R, Jan. 30, 2014 http://www.nytimes.com/2014/01/31/opinion/we-are-giving-ourselves-cancer.html Accessed February/March 2015.

28. Daily Mail Newspaper UK. Do regular mammograms raise the risk of cancer? Martin Scurr 16 Dec 2014 http: //www.dailymail.co.uk/health/article-2875052/Regular-mammograms-raiseriskcancer.html Accessed February/March 2015.

29. U.S. Food and Drug Administration What are the Radiation Risks from CT? 02/10/2015

http://www.fda.gov/RadiationEmittingProducts/RadiationEmittingProductsandProcedures/MedicalImaging/Me dicalX-Rays/ucm115329.htm Accessed February/March 2015.

30. New York Times. Radiation Worries for Children in Dentists' Chairs. Walt Bogdanich and Jo Craven Mcginty. November 22, 2010 http://www.nytimes.com/2010/11/23/us/23scan.html?pagewanted=all\&_r=0\#h[] Accessed February/March 2015.

31. Fox News. Many people unaware of radiation risk from CT scans. Genevra Pittman. Jan 4, 2013. http:/www.foxnews.com/health/2013/01/04/many-people-unaware-radiation-risk-from-ct-scans Accessed February/March 2015.

32. Medscape AHA Statement: How to Up Radiation Safety in CV Imaging. Marlene Busko October 03, 2014 http://www.medscape.com/viewarticle/832717 Accessed February/March 2015.

33. Donnelly LF, Frush DP, Rosen NS. Computed tomography and radiation risks: what pediatric health care providers should know. Pediatrics. 2003;112: 951-964.

34. de Jong PA, Mayo JR, Golmohammadi K, et al. Estimation of cancer mortality associated with repetitive computed tomography scanning. Am J Respir Crit Care Med 2006;173:199-203. 
35. Brenner DJ, Hall E, Cancer risks from Ct Scans: Now We Have Data, What Next? Radiology 2012;

265:330-331

36. Brenner DJ, Radiobiology special feature: review article; what we know and what we don't know about cancer risks associated with radiation doses from radiological imaging. Br J Radiol;87:2013 0629

37. Redberg RF, Cancer Risks and Radiation Exposure From Computed Tomographic Scan. Arch Intern Med. 169: 2009; 2049-2050

38. Voss S D, Gregory H. Reaman, Kaste SC, Slovis TL The ALARA concept in pediatric oncology. Pediatr Radiol (2009) 39:1142-1146

39. Slovis T. L. Editorial The ALARA Concept in Pediatric CT: Myth or Reality. Radiology 2002; 223:5-6 40. Willis Charles E. Thomas L. Slovis T. The ALARA concept in pediatric CR and DR: dose reduction in pediatric radiographic exams - A white paper conference Executive Summary Pediatr Radiol (2004) 34(Suppl 3): S162-S164

41. Frush DP, Donnelly LF, Rosen NS. Computed tomography and radiation risks: what pediatric health care providers should know [review article]. Pediatrics. 2003;112:951-957

42. Slovis T.L Children, Computed Tomography Radiation Dose, and the As Low As Reasonably Achievable (ALARA) Concept Pediatrics 2003;112;971

43. Lauer MS, Elements of Danger — The Case of Medical Imaging NEJM 2009;361:841 - 842

44. Smith-Bindman R.Is Computed Tomography Safe? N Engl J Med 2010; 363:1-4

45. Schroeder AR, Redberg RF. The harm in looking. Editorial. JAMA Pediatrics 2013; 167:693 - 695

46. Miglioretti DL Eliminating high-dose, unnecessary pediatric CT scans could reduce imaging-related cancers by two-thirds. JAMA Pediatr. doi:10.1001/jamapediatrics.2013.311.

47. Miglioretti DL, Johnson E, Williams A, et al. The use of computed tomography in pediatrics and the associated radiation exposure and estimated cancer risk. JAMAPediatr.2013;167:700-707

48. Pearce MS, Salotti JA, Little MP, et al. Radiation exposure from CT scans in childhood and subsequent risk of leukaemia and brain tumours: a retrospective cohort study. Lancet 2012; 380: 499-505. 
49. Mathews JD, Forsythe AV, Brady Z. et.al. Cancer risk in 680,000 people exposed to computed tomography scans in childhood or adolescence: data linkage study of 11 million Australians BMJ 2013; 346: f2360.

50. Journy N, Rehel JL, Ducou H et al. Are the studies on cancer risk from CT scans biased by indication? Elements of answer from a large-scale cohort study in France. British Journal of Cancer. 2015; 112: $185-193$. 51. Krille L, Dreger S, Schindel R, Albrecht T et al. Risk of cancer incidence before the age of 15 years after exposure to ionising radiation from computed tomography: results from a German cohort study. Radiat Environ Biophys 2015; 54:1-12

52. Consumer reports May 2015 page 5. Readers Letters. The benefits and risks of Medical Radiation. Allen B 53. Goske M.J, Applegate K, Boylan J, et al. The Image Gently Campaign: Working Together to Change Practice AJR: 2008; 190:272-274

54. Muratore CS. Pediatric abdominal CT scans: do it correctly. Better yet, don't do it at all. Journal of surgical research. DOI: http://dx.doi.org/10.1016/j.jss.2012.08.005

55. Brenner DP, Hricak H. Radiation Exposure from Medical Imaging Time to Regulate? JAMA 2010; 304: $208-209$

56. Fazel R, Gerber TC, Balter S, et.al. Approaches to Enhancing Radiation Safety in Cardiovascular Imaging. A Scientific Statement From the American Heart Association Circulation. 2014;130:1730-1748

57. Frush DP, Goske MJ, Image Gently: toward optimizing the practice of pediatric CT through resources and dialogue. Pediatric Radiology. 2015; 45:471-475

58. Newman B, Callahan M. ALARA (as low as reasonably achievable) CT 2011-executive summary Pediatr Radiol (2011) 41 (Suppl 2):S453-S455 